\title{
Influence of environmental disturbances on the bacteriological quality of Pagbanganan River in Baybay City, Leyte, Philippines
}

Jayzon G. Bitacura*

\begin{abstract}
Microorganisms like bacteria are frequently used as indicators of water quality in freshwater ecosystems. Thus, this study was conducted to evaluate the total coliforms (TC) and total aerobic heterotrophic bacteria (TAHB) present in the upstream (Kantagnos), midstream (Igang), and downstream (Kan-ipa) of Pagbanganan River. The most probable number (MPN/100mL) of TC was determined through multiple tube fermentation test while counts of TAHB present in both water and sediments were enumerated by serial dilution and plating methods. MPN of TC revealed that the river water should not be used as a source of public water supply and as a venue for contact recreational activities like bathing and swimming. Furthermore, TAHB in the sediments of the river did not differ significantly across sites although their values showed a decreasing trend. Conversely, TAHB in the water column of the river significantly increased from upstream to downstream. These results are most probably influenced by the quarrying activities present in the area. In the upstream where there is no quarrying activity, TAHB was higher in sediment than in the water, while in the downstream where quarrying activities are present, it is otherwise. Because of these significant differences, it is believed that the ratios of TAHB present in the water column and sediments are potential indicators of sediment disturbance in the aquatic environment. The results of this study imply that proper management of Pagbanganan River by all sectors of the community is needed to keep it sustainable for safe use.
\end{abstract}

Keywords: indicator bacteria, water quality, freshwater ecosystem, anthropogenic impact

\section{INTRODUCTION}

Rivers are considered as one of the important resources in the country in terms of anthropogenic activities and ecosystem conservation. The water quality of these

'Department of Biological Sciences, Visayas State University, Visca, Baybay, Leyte 6521-A

*Corresponding Author. Address: Department of Biological Sciences, Visayas State University,Visca, Baybay, Leyte6521-A;Email: jayzon.bitacura@vsu.edu.ph

DOI:10.32945/atr4117.2019 
aquatic ecosystems is essential for the maintenance of the biotic and ecological integrity because many organisms depend on it for survival. However, nowadays, rivers are threatened by water quality problems due to agricultural run-off, organic material, fertilizer and other potential contaminants (Vié et al 2009). They serve as recipients of pollutants from both atmosphere and the landscape leading to being good indicators of cumulative impacts (Hunsaker \& Levine 1995).

The major water quality problems in river ecosystems are organic pollutants, salinity, total suspended solids, heavy metals, eutrophication, nitrate, organic micro-pollutants and acidification (Meybeck \& Helmer 1989). Nonpoint source pollution like loading of nutrients, sediment, and other pollutants (Hunsaker \& Levine 1995) is a serious problem as well that degrades surface water quality and aquatic ecosystems. Attention to water quality is an absolute requirement for the health of lotic freshwater ecosystems. The overall health and integrity of a river can be assessed based on physico-chemical and biological indicators. The biological components of the river such as microorganisms, plankton, macrophytes, fishes, macroinvertebrates and the riparian vegetation can significantly determine water quality and overall ecological status of a river (Jafari \& Gunale 2006).

Microorganisms like bacteria have been constantly used as indicators of riverine water quality (Doherty et al 2017, Paulson et al 2016, Balmonte et al 2016). This is due to the presence of different bacterial species like Bacteroides thetaiotaomicron which is a human source tracking marker (Verhougstraete et al 2015) and Escherichia coli as a fecal indicator bacteria (Causse et al 2015). However, when there are several possible sources of pollution it is better to study bacterial groups rather than only one species. For instance, the abundance of aerobic heterotrophic bacteria indicates high organic pollution (Todorova et al 2017) while the abundance of coliforms is one of the parameters in determining the classification and in recommending the uses for a particular water body (DAO 1990).

One of the 12 major rivers in the island of Leyte in the Philippines is the Pagbanganan River, which traverses about nine barangays in the city of Baybay. The watershed that drains into this river and tributaries covers an area of about $16,762 \mathrm{ha}$ and is classified as a fifth-order basin with 117 streams of all orders. Pagbanganan River is considered as an important source of food and other resources to the nearby communities belonging to low-income families. However, these communities believed that the quality of the river is slowly deteriorating over time (Labonite et al 2013). The most evident disturbance that occurs in the area is the quarrying of the sand and gravel for industrialization purposes. As of the present, no reports on the water quality of Pagbanganan River is available. Thus, this study evaluated the abundance of coliform and aerobic heterotrophic bacteria as bioindicators to determine how environmental disturbances are contributing to the perceived slow deterioration of the river. The results generated are vital in supporting the existing efforts on the protection of rivers in the country.

\section{MATERIALS AND METHODS}

\section{Establishment and Description of Sampling Sites}

A reconnaissance survey was done to identify the three sites in Pagbanganan River, Baybay City, Leyte. Three stations were selected: in the upstream (Site 1), 
Influence of environmental disturbances on the bacteriological quality

midstream (Site 2) and downstream (Site 3) which were about 7-8km from each other. Site 1 was in Brgy. Kantagnos; Site 2, in Brgy. Igang; and Site 3, in Brgy. Kanipa. These sites were selected based on the level of disturbance identified in the areas (Table $1 \&$ Figure 2). Geographic coordinates were taken at each station using a Global Positioning System (GPS). Selected stations were mapped with coordinates using the Google earth (Figure 1).

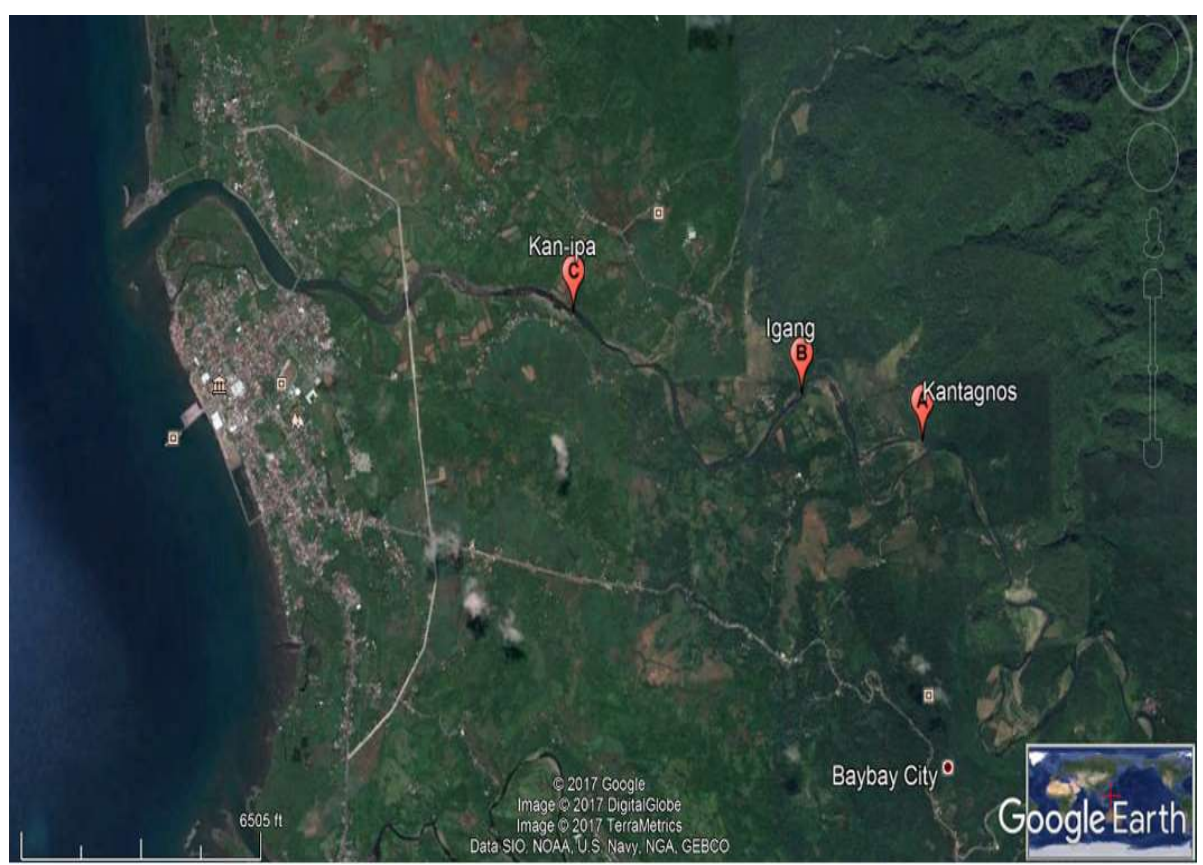

Figure 1. Map showing the sampling sites (red marks) in Pagbanganan River, Baybay City, Leyte, Philippines. Source: Google Earth 2017

Table 1. Characteristics of the identified sampling sites in Pagbanganan River, Baybay City, Leyte

\begin{tabular}{llll}
\hline \multicolumn{1}{c}{ Site } & Location & Disturbance/S Present & Level of Disturbance \\
\hline Kantagnos & Upstream & $\begin{array}{l}\text { Input from upper part of the } \\
\text { river }\end{array}$ & less \\
Igang & Midstream & $\begin{array}{l}\text { Wallowing of Carabaos, } \\
\text { Laundry washing }\end{array}$ & moderate \\
Kan-ipa & Downstream & $\begin{array}{l}\text { Wallowing of Carabaos, } \\
\text { Quarrying }\end{array}$ & high \\
& &
\end{tabular}


Bitacura
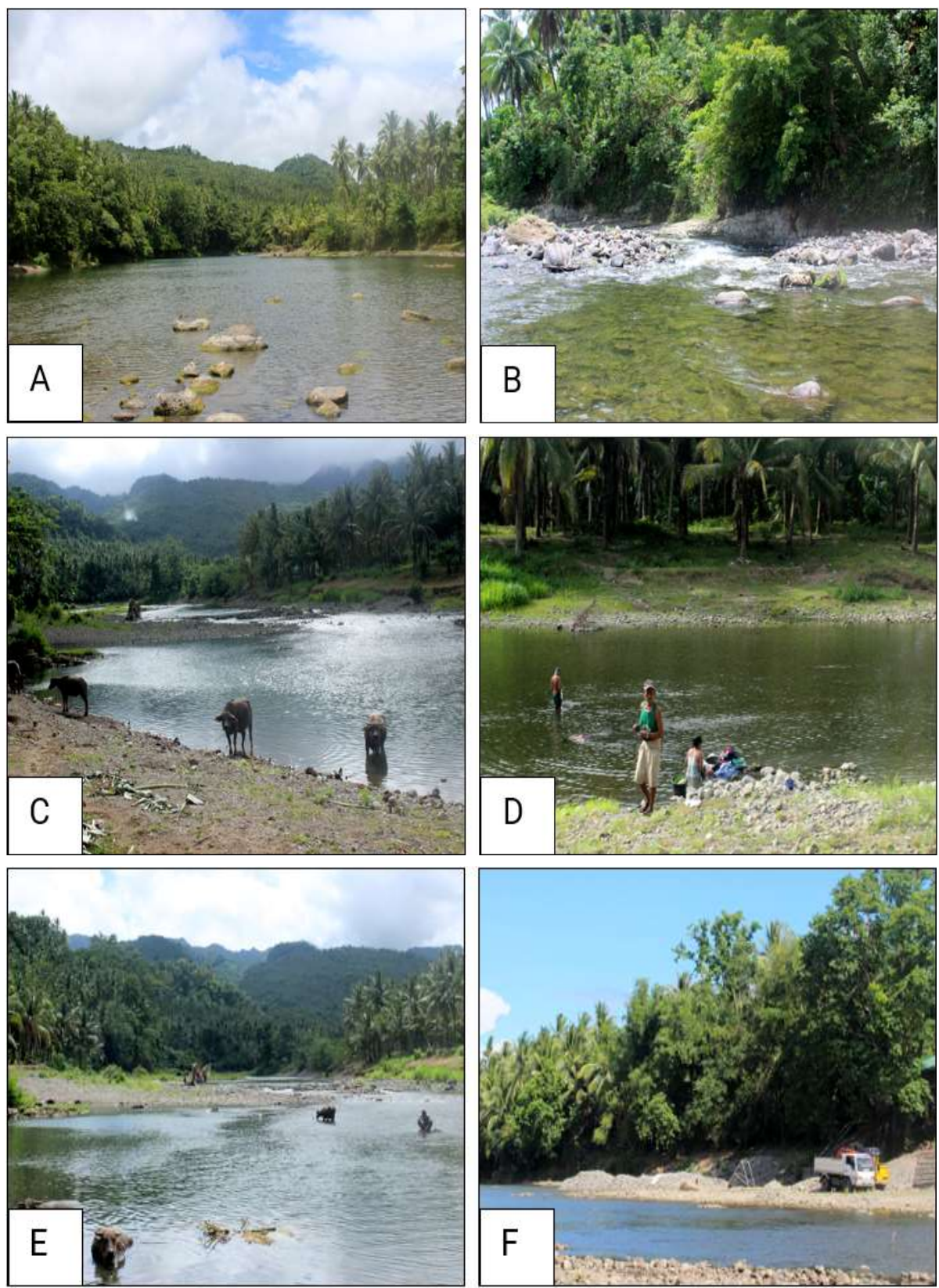

Figure 2. The identified sampling sites in Pagbanganan River, a \& b) Kantagnos in upstream, c \& d) Igang in midstream, and e \& f) Kan-ipa in downstream 
Influence of environmental disturbances on the bacteriological quality

\section{Collection of Sediment and Water Samples}

Water and sediment samples were collected in autoclaved sterile containers from each station with three replicates each. In getting water samples from rivers, bottles were submerged with the mouth facing against the current. Water was allowed to overflow inside the bottle and covered immediately (Bordner \& Winter 1978). For sediment sampling, the method of Zhang et al (2016) was adapted using a grab sampler. The sampler typically consists of paired weighted rectangular jaws that close when submerged to the surface of the sediment. It has vent holes that permit water to flow through while the grab is submerged. Cross-contamination between sites was minimized by thoroughly and carefully cleaning the grab sampler before changing the sampling stations Water and sediment sampling in every site was done in triplicates. All samples were kept on ice and were immediately brought to the laboratory for bacteriological analyses within $24 \mathrm{~h}$.

\section{Bacteriological Analyses}

\section{Preparation of media}

Lactose broth was used to determine the most probable number of total coliforms (TC) per $100 \mathrm{~mL}$ of water samples (MPN/100mL) while nutrient agar (NA) was used to quantify total aerobic heterotrophic bacteria (TAHB) present in water and sediment samples.

For the preparation of lactose broth, $3 \mathrm{~g}$ of beef extract (Scharlau, Scharlab Philippines. Inc.), $5 \mathrm{~g}$ of peptone (Sigma-Aldrich, Sigma-Aldrich. Inc.) and $10 \mathrm{~g}$ of lactose (Scharlau, Scharlab Philippines. Inc.) were mixed in a $500 \mathrm{~mL}$ distilled water. The mixture was preheated to completely dissolve. When the mixture was homogenous, $30 \mathrm{~mL}$ of bromthymol blue (Sigma-Aldrich, Sigma-Aldrich Inc) was added. It was decanted in a volumetric flask and added with distilled water to obtain $1 \mathrm{~L}$ freshly prepared lactose broth. On the other hand, for the preparation of NA, $23 \mathrm{~g}$ nutrient agar (Scharlau, Scharlab Philippines Inc) was weighed and mixed in $1 \mathrm{~L}$ distilled water. Mixture was stirred and preheated to completely dissolve. All prepared media were autoclaved at $121^{\circ} \mathrm{C}, 15$ psi for $15 \mathrm{~min}$.

\section{Determination of the most probable number of total coliforms}

Most Probable Number (MPN) of total coliforms in water samples were determined through multiple tube fermentation test (recommended procedure for classifying coastal \& freshwater bodies based on Section 68 of Department of Environmental and Natural Resources (DENR) Administrative Order No. 34 Series 1990).

In this test, there were three groups of five tubes containing lactose broth. The samples were inverted several times to ensure mixing of samples. Using a sterile pipet, $10 \mathrm{~mL}$ from the sample was transferred into 5 tubes, $1 \mathrm{~mL}$ into the other 5 tubes and $0.1 \mathrm{~mL}$ into the last 5 tubes of lactose broth. Each tube was covered with cotton plugs. The tube was swirled gently until the samples were well mixed with the nutrient medium. Each tube was examined to make sure that the inner tube was filled with liquid with no bubbles. The tubes were incubated for $24 \mathrm{~h}$. Incubation was at room temperature. After one hour of incubation, bubbles appeared, so the 
tubes were inverted or tapped to release the bubbles inside the inner tube. Then, tubes were returned to its vertical position. After $24 \mathrm{~h}$, tubes were examined. Tubes were tapped to see gas formation inside the inner tube and when broth was cloudy, the samples containing coliform bacteria were considered positive. Bubbles and gas formation are due to lactose fermentation by coliform bacteria.

Positive tubes from $10 \mathrm{~mL}, 1 \mathrm{~mL}$ and $0.1 \mathrm{~mL}$ were counted. The combination of the positive tubes from the three different dilutions gathered the MPN index of coliform per $100 \mathrm{~mL}$ of water sample. After obtaining the MPN/ $100 \mathrm{~mL}$ of the water samples, it was then categorized and classified to its following beneficial uses according to Section 68 of DENR Administrative Order No. 34 Series of 1990.

\section{Quantification of total aerobic heterotrophic bacterial load}

Water samples were diluted by transferring $1 \mathrm{~mL}$ from the tube with the samples into $9 \mathrm{~mL}$ of distilled water. The dilution was $1^{-1}$ and further diluted until $1^{-5}$. There were three replicates in each diluted tube in every agar medium. From the diluted tube $1^{-3}$ to $1^{-5}, 0.1 \mathrm{~mL}$ was pour-plated in NA agar in triplicates. The plates were swirled gently to ensure even distribution of the bacterial cells. As the media solidified, the plates were sealed, inverted and incubated at room temperature for 24-48h. The same method was done for sediments except $1 \mathrm{~g}$ of sediment samples were used in the dilution process.

From the colonies counted on the plates the total aerobic heterotrophic bacteria (TAHB) of the water and sediment samples were determined and were recorded as $\mathrm{CFU} / \mathrm{g}$ or $\mathrm{mL}$ of sediment and water samples, respectively.

\section{Statistical Analysis}

Single factor ANOVA was used to determine the significant differences in the TAHB of the waters and sediments across the three sampling sites in Pagbanganan River followed by post-hoc comparison of means using Tukey's HSD. On the other hand, T-test was used for the comparison of TAHB between the water and sediment in every site. All the analysis was done using STATA.

\section{RESULTS AND DISCUSSION}

\section{Classification and Recommended Beneficial Uses of Pagbanganan River}

The most probable numbers of TC (MPN/100mL) in Pagbanganan River reveal that the waters in all sites studied are categorized as surface freshwater Class $C$ (Table 2) based on DAO no. 34,s. 1990. This means that these waters are not recommended as a source of public water supply and for contact recreational activities like bathing and swimming. These waters are only recommended for fish culture (for the propagation \& growth of fish \& other aquatic resources), recreational water supply class II, industrial water supply or for agriculture, irrigation, livestock watering, etc. Recreational water supply class II, are those waters that could only be used for non-contact recreational activity like boating while those classified as industrial water are recommended for manufacturing processes after treatment. 
Influence of environmental disturbances on the bacteriological quality

Table 2. Water classification and recommended beneficial uses of Pagbanganan River based on the most probable number of TC per $100 \mathrm{~mL}$ of the water samples

\begin{tabular}{|c|c|c|c|}
\hline Stations & MPN/100mL & Class & Beneficial Uses \\
\hline Kantagnos (upstream) & $>1600$ & C & $\begin{array}{l}\text { (1) Fishery Water; } \\
\text { (2) Recreational Water Supply Class II; } \\
\text { (3) Industrial Water Supply Class I }\end{array}$ \\
\hline Igang (midstream) & $>1600$ & C & $\begin{array}{l}\text { (1) Fishery Water; } \\
\text { (2) Recreational Water Supply Class II; } \\
\text { (3) Industrial Water Supply Class I }\end{array}$ \\
\hline Kan-ipa (downstream) & $>1600$ & C & $\begin{array}{l}\text { (1) Fishery Water; } \\
\text { (2) Recreational Water Supply Class II; } \\
\text { (3) Industrial Water Supply Class I }\end{array}$ \\
\hline (+) Control & $>1600$ & C & $\begin{array}{l}\text { (1) Fishery Water; } \\
\text { (2) Recreational Water Supply Class II; } \\
\text { (3) Industrial Water Supply Class I }\end{array}$ \\
\hline (-) Control & 0.00 & AA & Public Water Supply Class I \\
\hline
\end{tabular}

Anthropogenic activities influence the abundance of coliform in a water body (Cheah \& Hamid 2016, Verhougstraete et al 2015). According to Causse et al (2015) contamination of the rivers with coliforms like $E$. coli is controlled by both land use and hydrology. Outdoor defecations of humans and livestock continuously feed stock of bacteria to the topsoil, and through overland flow during rainy days the bacteria laden waste subsequently mobilize to the adjacent rivers. This may be the case of the waters in Pagbanganan River. The river's coliform abundance could be attributed to some practices by the communities residing near the river. According to the report of Labonite et al (2013) almost $17 \%$ of the communities residing near the Pagbanganan River simply dump their trash in the river, $18.2 \%$ do not have their own toilets and almost $13 \%$ of the households use the river for wallowing carabaos.

\section{Abundance of Aerobic Heterotrophic Bacteria in Pagbanganan River}

Table 3 shows the occurrence of aerobic heterotrophic bacteria in the waters and sediments of Pagbanganan River. The TAHB in the river ranges from 100,000 up to more than 250,000 colonies forming unit per $\mathrm{ml}$ of water and from $\sim 150,000$ up to more than 200,000 colonies per gram of the sediments. Comparison of TAHB present in the sediments and waters in every site revealed that significant differences in the occurrence of aerobic heterotrophic bacteria were present in Kantagnos (upstream) and Kan-ipa (downstream), and it was only in Igang (midstream) where no significant difference in TAHB occurred. TAHB abundance significantly differed only among the waters and not among the sediments across the sites. TAHB were highest in the waters of Kan-ipa (downstream) and least at 
Kantagnos (upstream) (Figure 3). The results indicate that there is an increasing trend of TAHB in the waters of the river. Although the TAHB found in the sediments of the river did not differ significantly across the sites TAHB values still showed a decreasing trend from upstream to downstream of Pagbanganan River (Figure 3).

Table 3. Abundance of aerobic hetrotrophic bacteria in the sediments and waters of Pagbanganan River

\begin{tabular}{lcccc}
\hline \multirow{2}{*}{ Sites } & \multicolumn{4}{c}{ Total Aerobic Heterotrophic Bacteria } \\
\cline { 2 - 5 } & \multicolumn{2}{c}{ Sediments } & \multicolumn{2}{c}{ Water } \\
\cline { 2 - 5 } & 221111.11 & $( \pm 64700.16)$ & 103333.33 & $( \pm 26925.82)$ \\
\hline Kantagnos (upstream) & 183333.33 & $( \pm 40311.29)$ & 155555.56 & $( \pm 99008.98)$ \\
Igang (midstream) & 147777.78 & $( \pm 43237.07)$ & 251111.11 & $( \pm 79442.50)$ \\
Kan-ipa (downstream) & 215555.56 & $( \pm 39405.30)$ & 147777.78 & $( \pm 46577.30)$ \\
$(+)$ Control & 000000.00 & $( \pm 00000.00)$ & 000000.00 & $( \pm 00000.00)$ \\
$(-)$ Control & & & &
\end{tabular}

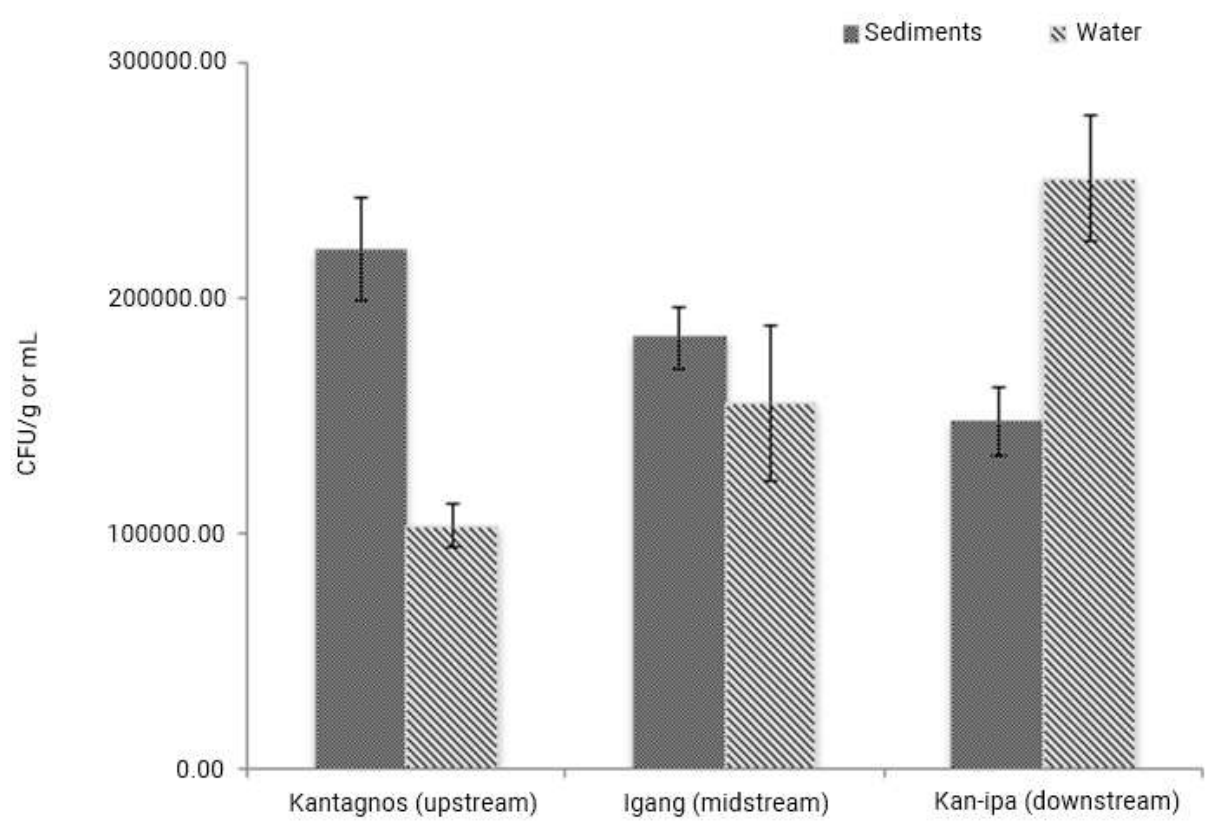

Figure 3. Comparison of the abundance of total aerobic heterotrophic bacteria (CFU/ $\mathrm{g}$ or $\mathrm{mL} \pm \mathrm{SE}$ ) across the three sampling sites and between the sediments and waters of Pagbanganan River. *significantly different at $p<0.05$, while sites connected by same letters are not significantly different $(p<0.05)$

According to Todorova et al (2017) freshwater sediments are important reservoir of bacteria for surface waters where organic pollutants are deposited and accumulated. With the observed trends in the TAHB of waters and sediments from upstream to downstream of Pagbanganan River, TAHB water to sediment ratio was obtained as a potential indicator of sediment disturbance in the river. A value of one 
Influence of environmental disturbances on the bacteriological quality

(1) would mean that there is equal abundance of TAHB in both waters and sediments. Below one $(<1)$ would mean that the sediments have higher TAHB load implying less disturbance in the sediments while above one $(>1)$ would mean that the waters have higher TAHB load than the sediments implying high sediment disturbance.

Figure 4 shows that upstream and midstream of Pagbanganan River has TAHB water to sediment ratio of less than one $(<1)$. These results imply that the level of sediment disturbance in the sediments in these parts of the river may not have significantly affected the bacterial population in the water. In the downstream of the river, TAHB water to sediment ratio value is above one $(>1)$, which reveals that the sediment disturbance has significantly affected the abundance of TAHB in the waters. These results are consistent with the comparison of TAHB load between the waters and sediments of the three sites (Figure 3): Upstream where there is least disturbance identified is where water TAHB is significantly lower than sediment TAHB. In the downstream, where more disturbances are identified, is where water TAHB is significantly higher than the sediments.

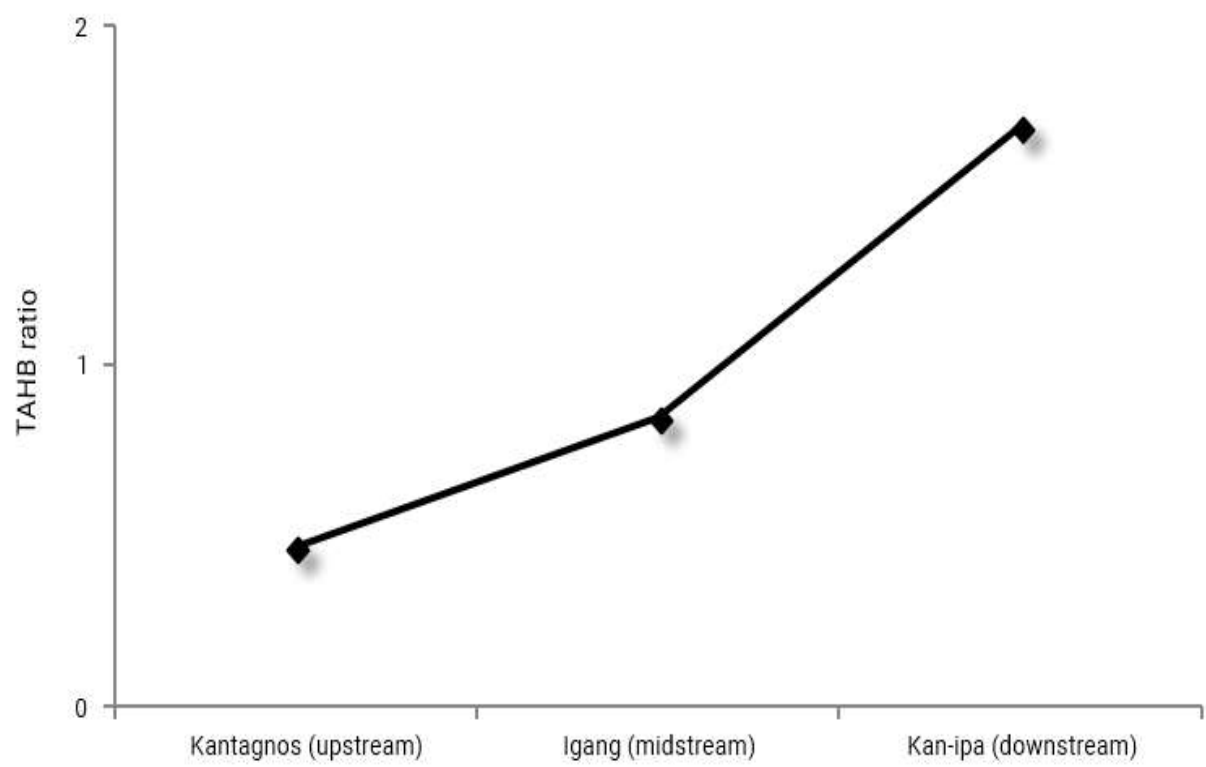

Figure 4. Water to sediment ratios of TAHB from upstream to downstream of Pagbanganan River

Hydrological alterations are important in structuring bacterial communities (Balmonte et al 2016). Thus, bacterial abundance is a good index to distinguish domestic and industrial pollution, especially when the main pollution sources are difficult to identify ( $\mathrm{Li}$ et al 2017). In Pagbanganan River the TC bacterial load already shows how possible pollutants affect river bacterial quality. Conversely, TAHB water to sediment ratio shows how quarrying activities increase bacterial abundance in the water. The disturbance of sediments through quarrying does not just liberate the bacteria present in the sediments to the water, it also amplifies their 
abundance by making the nutrients deposited in the sediments freely available to them. Nutrients like phosphates are relatively stable in the sediments because they form bonds with soil particles (Schumacker \& Whitford 1965). Thus, any disturbance in sediment would help release these phosphates into the water column for utilization by bacteria. According to Labonite and Belonias (2013), the concentration of phosphate in Pagbanganan River exceeded the freshwater normal range as set by DAO 34 (1990). They have attributed the high quantity of phosphates to laundry soaps and commercial cleaning fluids used by the residents when doing their laundry in the river, as well as to the fertilizer run offs from nearby farm lands and to the excreta of farm animals wallowing in the river.

\section{CONCLUSION}

This study has shown that anthropogenic activities have influenced the bacteriological quality of Pagbanganan River. Abundance of coliforms in Pagbanganan River reveals that the river should not be used as a source of public water supply and as a venue for contact recreational activities like bathing and swimming. These waters are only recommended as a fishery water, recreational water supply class II, industrial water supply or for agriculture, irrigation and livestock watering. Furthermore, the trend in the abundance of aerobic heterotrophic bacteria in the river suggests that a disturbance in the sediment could significantly contribute to the growth of these bacteria in the water column. The results of this study are an affirmation that Pagbanganan River needs critical evaluation, close monitoring, and proper management by the local government and nearby communities to keep it sustainable for safe water use.

\section{ACKNOWLEDGMENT}

The authors would like to thank the following institution and individuals who helped make this study possible: Visayas State University for funding this study under the project "Biological and Socio-Ecological Characterization of Major River Systems in Leyte", the project leader Dr. Beatriz S. Belonias, and Ms. Eushebelle S. Laurente, Ms. Honey Dela Torre and Ms. Shirley Quiñones for the assistance during sampling and laboratory analysis.

\section{REFERENCES}

Balmonte JP, Arnosti C, Underwood S, Mckee BA \& Teske A. 2016. Riverine bacterial communities reveal environmental disturbance signatures within the Betaproteobacteria and Verrucomicrobia. Frontiers in Microbiology 7:1441. doi: $10.3389 /$ fmicb.2016.01441

Bordner R and Winter J. 1978. Microbiological Methods for Monitoring the Environment.U.S. Environmental Protection Agency Cincinnati. Ohio 45268

Causse J, Billen G, Garnier J, Henri-Des-Tureaux T, Olasa X, Thammahacksa C, Latsachak KO, Soulileuth B, Sengtaheuanghoung O, Rochelle-Newall E \& Ribolzi 0.2015 . Field and Modelling Studies of Escherichia coli loads in tropical streams of montane agro-ecosystems. Journal of Hydro-environment Research 9(4):496507. http://dx.doi.org/10.1016/j.jher.2015.03.003 
Influence of environmental disturbances on the bacteriological quality

Cheah EHMR and Hamid SA. 2016. Determination of water quality of rivers under various land use activities using physico-chemical parameters and bacterial populations in Northern Peninsular Malaysia. Wetland Science 14(6):788-798

DENR Administrative Order No. 34 Series of 1990. Revised water usage and classification/water quality criteria amending Section Nos. 68 and 69, Chapter III of the 1978 NPCC rules and regulation

Doherty M, Yager PL, Moran MA, Coles VJ, Fortunato CS, Krusche AV, Medeiros PM, Payet JP, Richey JE, Satinsky BM, Sawakuchi HO, Ward ND \& Crump BC. 2017.Bacterial biogeography across the Amazon River-Ocean continuum. Frontiers in Microbiology 8. doi: 10.3389/fmicb.2017.00882

Hunsaker CT and Levine DA. 1995. Hierarchical approaches to the study of water quality in rivers: spatial scale and terrestrial processes are important in developing models to translate research results to management practices. BioScience 45(3):193-203

Jafari NG and Gunale VR. 2006. Hydrobiological study of algae of an urban freshwater river. Journal of Applied Sciences \& Environmental Management 10(2):153-158

Labonite EKA and Belonias BS. 2013. Community structure of planktonic algae in Pagbanganan River, Baybay City, Leyte. Science and Humanities Journal 10:5482

Labonite EKA, Seriño MNV \& Belonias BS. 2013. Perceptions of local communities on water quality in Pagbanganan River, Baybay City, Leyte. Science and Humanities Journal 10:98-120

Li D, Jiang X, Wang J, Wang K \& Zheng B. 2017. Effect of sewage and industrial effluents on bacterial and archaeal communities of creek sediments in the Taihu Basin. Water 9(6):373. doi:10.3390/w9060373

Meybeck M and Helmer R. 1989. The quality of rivers: from pristine stage to global pollution. Palaeogeography, Palaeoclimatology, Palaeoecology 75(4):283-309

Paulson JR, Mahmoud IY, Al-Musharafi SK \& Al-Bahry SN. 2016. Antibiotic Resistant Bacteria in the Environment as Bio-Indicators of Pollution. The Open Biotechnology Journal 10: 342-351. doi:10.2174/1874070701610010342

Schumacher GJ and Whitford LA. 1965. Respiration and P-uptake in various species of freshwater algae as affected by current. Journal of Phycology 1:78-90

Todorova Y, Yotinov I, Todorova D \& Topalava Y. 2017. Sediment microbial community profile in upper part of Iskar River. Ecological Engineering and Environment Protection 9:7-15

Verhougstraete MP, Martin SL, Kendall AD, Hyndman DW \& Rose JB. 2015. Linking fecal bacteria in rivers to landscape, geochemical, and hydrologic factors and sources at the basin scale. Proceedings of the National Academy of Sciences of the United States of America. doi:10.1073/pnas.1415836112

Vié JC, Hilton-Taylor C \& Stuart SN. 2009. Wildlife in a Changing World-An Analysis of the 2008 IUCN Red List of Threatened Species (pp180). Gland, Switzerland: IUCN

Zhang X, Gu Q, Long XE, Li ZL, Liu DX, Ye DH, He CQ, Liu XY, Väähähen K \& Chen XP. 2015. Anthropogenic activities drive the microbial community and its function in urban river sediment. Journal of Soils and Sediments 16(2):716-725. doi:10.1007/s11368-015-1246-8 